\title{
Just How Marginal Was Machado de Assis? The Early Translations and the Borges Connection
}

\author{
Rhett McNeil \\ The Pennsylvania State University
}

Brazilian literature is traditionally understood-by writers, critics, and scholars alike-to have developed in relative isolation from the literatures of Hispanophone Latin America, inhabiting a peripheral cultural space within the already peripheral sphere of Latin American literature. Though Brazil is certainly seen as an important economic and political force today, it is generally considered to be isolated from the cultural capitals of Europe and the U.S., and even from the rest of Latin America, from which it is separated linguistically, if not always geographically. Perhaps the most striking example of this traditional conception is the commonly held assumption of the complete separation of two of Latin America's most renowned fiction writers: the Brazilian Joaquim Maria Machado de Assis and the Argentine Jorge Luis Borges. Though there have been a handful of critics and writers who have found similarities in the fictional oeuvres of Machado and Borges (including Carlos Fuentes, Luis Augusto Fischer, and Earl E. Fitz), they all assume that there is no clear literary-historical connection between them, principally because Borges never makes mention of his Brazilian precursor, yet also because of Brazil's reputation as a linguistically isolated periphery lying outside the dominant Hispanophone culture of Latin America. Fitz sums up the critical consensus nicely when he states: "Brazilian literature evolved in almost complete isolation from Spanish American literature. Even Jorge Luis Borges, who seems to have read everyone else, never mentions the Brazilian master Machado de Assis" (23). As such, Machado de Assis is often regarded as inhabiting a double cultural periphery, as both a Latin American writer and a Brazilian, who, furthermore, wrote in a "minor" language, never traveled outside of his own country, and rarely ever left his native Rio de Janeiro. Another enduring belief, tangential to the tale of Brazil's cultural isolation, is that Machado de Assis's work went untranslated, by and large, until about half a century after his death. Yet the early translation history of Machado de Assis's work-regarding the translations that were published during the last decade of his life and the first couple of decades thereafter-offers a fascinating insight into the literary ties that connect 
Machado's work to the dominant literary cultures of the Americas and Europe and provides a literary-historical link between Machado de Assis and Jorge Luis Borges.

Curiously, the connection between Machado and Borges, whose countries share a border, follows a route of translational cultural exchange through France and Spain, and involves a prolific translator who was both the first Spanish translator of Machado's short fiction and the mentor of a young Borges: Rafael Cansinos Assens. As such, the early history of Machado's fiction in translation demonstrates that Machado is a much less peripheral figure than previously imagined, and that, through Machado, Brazilian literature is more intimately intertwined with the literatures of Hispanophone Latin America and the cultural capitals of Europe-ostensibly the centers of cultural production in the West—-than critics and scholars have recognized.

The early history of Machado's fiction in translation contrasts strikingly with the standard critical practice of reinscribing Machado de Assis into an isolated, peripheral cultural space, devoid of influence outside of his small, provincial sphere in late- $19^{\text {th }}$ century Rio de Janeiro. This critical perspective is so prevalent that it has spread from expert scholars in the field of Latin American literature-like Emir Rodríguez Monegal and Earl E. Fitz-to more generalist cultural and literary critics, such as Susan Sontag. Sontag's preface to William Grossman's English-language translation of Machado de Assis's novel Memórias póstumas de Brás Cubas (entitled Epitaph of a Small Winner in Grossman's version) provides an excellent example of the way that the clichéd critical discourse around Machado serves to relegate him to a cultural periphery that his own translation history belies. Throughout the preface, Sontag bemoans the fact that Spanish-language Latin American authors are generally unaware of literary developments in Brazil, and uses Borges's ignorance of Machado's work as a glaring example of this unawareness: "Borges, the other supremely great writer produced on that continent, seems never to have read Machado de Assis. Indeed, Machado is even less well known to Spanish-language readers than to those who read him in English" (39). Sontag goes on to discuss the belated translation of Brás Cubas into Spanish, claiming that it was "finally translated into Spanish only in the 1960s, some eighty years after it was written and a decade after it was translated (twice) into English" (39). On this point, however, she is mistaken and gives the U.S. translation too much credit. In reality, Brás Cubas was published in Spanish way back in 1902-first serially, then in book form-in 
Montevideo, an important center of literary activity in the southern cone region of Latin America, and one with significant ties to Borges's hometown of Buenos Aires. Furthermore, this was the first-ever translation of Brás Cubas into any language, and one that Machado himself knew about, read, and praised.

In a letter to Luís Guimarães Filho dated 10 July 1902, Machado mentions receipt of the full Spanish translation of Brás Cubas: "Recebi a sua cartinha com as notícias que me dá, e o exemplar da tradução das Memórias Póstumas de Brás Cubas" ("I have received your little letter along with the news that it brought me, and the copy of the translation of the Posthumous Memoirs of Brás Cubas"; Obra Completa 3: 1060). ${ }^{1}$ Machado had already seen some of the translation that had been published in serial form in Montevideo, but at this point he was finally able to read it in its entirety. Furthermore, he heartily approved of the translation and heaped praise on the translator: "A tradução só agora a pude ler completamente, e digo-lhe que a achei tão fiel como elegante, merecendo Júlio [sic] Piquet ainda mais por isso os meus agradecimentos" "II was only just now able to read the translation in its entirety, and I can tell you that I found it to be as faithful as it is elegant, and thus Júlio [sic] Piquet is even more deserving of my gratitude"; 1060). Far afield from Sontag's mistaken ideas about the cultural divide between Brazil and the rest of Latin America, Piquet's 1902 translation of Brás Cubas and Machado's 1902 letter on the subject show that Machado was involved first-hand in the international exchange of his work in Latin America, that he was translated and read in the Rio de la Plata region (which encompasses the cultural capitals of Buenos Aires and Montevideo) much earlier than is commonly assumed, and that the ties between Brazilian and Hispanophone Latin American literature are, perhaps, closer than is generally imagined.

The 1902 Spanish translation of Brás Cubas by Uruguayan writer and journalist Julio Piquet was initially published in serial form in Montevideo, starting in January 1902, in a newspaper called La Razón. Later that same year it was published in book form by an imprint of La Razón, also in Montevideo. This is significant, given the geographical and cultural proximity between Montevideo and Buenos Aires, to which Borges would return twenty years later, after an extended stay in Europe as a young man. The second of the two translations to appear in Machado's lifetime was the Spanish-language edition of his 1904 novel Esaú e Jacó (Esau and Jacob), which was published in Buenos Aires in 1905 by

${ }^{1}$ All translations are mine. 
an imprint of the major Argentine newspaper La Nación. Piquet, who had lived in Brazil at some point, also appears to have been responsible for this translation (Rocca 46), which, shockingly, appeared on the bookshelves of Argentine bookshops just a year after its publication in Portuguese. Piquet was a prominent member of the Rio de la Plata literati at the time, as well as someone who had little regard for the linguistic and national borders that separated the cultures of Argentina and Uruguay from Brazil: " $[\mathrm{N}]$ o início do século XX era um dos jornalistas literários-por assim dizer-mais valorizados do Rio da Prata. Grande admirador e bom amigo de Rubén Darío, também o foi de Olavo Bilac"("At the beginning of the $20^{\text {th }}$ century, he was one of the literary journalists - to put it that way-most valued in the Rio de la Plata region. He was a great admirer and good friend of [the Nicaraguan] Rubén Darío, as well as [the Brazilian] Olavo Bilac"; Rocca 39). Thus, two of Machado's novels from his formally subversive second phase were available for public consumption in Buenos Aires during Machado's lifetime, a couple of decades before Borges and his family would return from Europe for good. Perhaps, then, Borges's early exposure to Machado de Assis occurred in Buenos Aires, facilitated by the Uruguyan Piquet's Spanish-language translations, the first-ever translations of Machado's work.

In light of these early translations in the Rio de la Plata region, Sontag's claims about Machado's obscurity among Spanish-language readers appear quite mistaken. Furthermore, her comments unfairly serve to reinforce Machado's peripheral place in world literature, even as she attempts to introduce more readers to one of his most formally experimental novels. Indeed, by the time that Sontag was writing about the disconnect between Machado and Borges, it seems that a handful of clichéd-if not completely true or verified-ideas about Machado and Brazilian literature had entered the critical consciousness. The first of these is that Brazilian literature developed in isolation from the rest of Latin America; for Sontag, this is the fault of Hispanophone South America: "A writer from these countries is far likelier to know any of the European literatures or literature in English than to know the literature of Brazil, whereas Brazilian writers are acutely aware of Spanish-American literature" (39). Secondly, this one-sided isolation is supposedly demonstrated by the fact that Borges never read Machado. So, not only is Brazilian literature ignored by the rest of South America, but Borges-whose wide-reading is notorious-was ignorant of his great Brazilian precursor. Finally, Sontag asserts that Hispanophone Latin America was 
incredibly late in translating Machado into Spanish, even later than the woefully cultural-isolationist U.S. While these assumptions are all, by now, standard truisms when it comes to the study of Latin American literature and the critical dialogue concerning Machado, they certainly need to be questioned, since, in each case, there is compelling evidence to the contrary — such as Piquet's early Spanish translations- that suggests new possibilities for our understanding of the history of Latin American fiction.

The subsequent translation and publication of Machado's work in Europe, in the decade following his death, also provides intriguing connections to Hispanophone Latin America, the literary culture of the Rio de la Plata region, and, perhaps, to Borges himself. Machado's work was first translated into French in the years just after his death in 1908, at the age of 69. In 1910, the Parisian publishing house Garnier Frères published a collection of Machado's short stories entitled Quelques Contes and, in 1911, published a translation of Memórias póstumas de Brás Cubas. The identity of the French publishing house provides a crucial insight into the intercultural exchange between Rio de Janeiro and Paris in the late $19^{\text {th }}$ and early $20^{\text {th }}$ century. The youngest of the frères of Garnier Frères had opened an offshoot of the Parisian publishing house in Rio de Janeiro in 1844; Garnier Irmãos, as it was called in Brazil, was a central part of the Brazilian publishing enterprise from its inception until the early $20^{\text {th }}$ century. Garnier Irmãos was located on the Rua do Ouvidor in central Rio, the heart of the Brazilian publishing industry, and was the original publisher of many of Machado's books, including Mémorias póstumas de Brás Cubas and Quincas Borba. The relatively quick appearance of Várias Histórias (the original Portuguese title of Quelques Contes) and Brás Cubas in French translation (within just a few years following Machado's death) can thus be explained, at least in part, by the fact that one of his main publishers in Rio was an offshoot of the very same Paris-based publishing house that would publish him in French translation in France.

Both of these French-language volumes were translated by Adrien Delpech, and the cultural identity of this translator is another reason why these books appeared in French so soon after their original publication in Rio. Delpech was a native of Belgium who had studied in Paris, then moved to Rio de Janeiro at the age of 25 in 1892, married a Brazilian woman and remained in Brazil for the rest of his life, until his death in 1942. In addition to being a translator, he was an author, journalist, and professor (lecturing on 
French, art, and even Brazilian literature), and one can imagine that without the happy coincidence of this Belgian polyglot and polymath residing in Rio, Machado's work would have taken somewhat longer to be translated and published in France. Furthermore, Quelques Contes isn't just a collection of "some short stories," as the French title might suggest; rather, it is a translation of an entire volume of short fiction that Machado published in Rio, with the rather generic, anthological title of Várias Histórias (which would roughly translate as Some Stories or Several Stories, and, therefore, Quelques Contes in French), first published in 1896 by Laemmert, another important publishing house on the Rua do Ouvidor in Rio.

Delpech's French translations of Machado's work seemingly had a ripple effect in Europe and the Americas, beginning in Spain. In 1916, the first translation of Machado's short fiction into Spanish was published in Madrid. The tome contained 11 of his short stories and was translated by the Spaniard Rafael Cansinos Assens. This volume has been largely forgotten and is often overlooked in the scholarship on Machado in translation. Carlos Alberto Pasero, for instance, in an article from 2000, makes reference to the 1939 Spanish-language publication of Machado's "Último Capítulo" and states that "tal vez sea la primera version castellana de un cuento machadiano" ("perhaps it is the first Spanish version of a short story by Machado"; 63). Not only is Pasero almost twenty-five years off, but he also fails to recognize that a whole volume of short stories was previously published in Spanish, making this publication of "Último capítulo," perhaps, the twelfth story to appear in Spanish.

Cansinos's volume of translations is, therefore, crucial for understanding Machado's afterlife in translation, specifically his impact on Spanish-language Latin American literature and perhaps even on Borges himself. The unattributed editorial forward to this volume, entitled Narraciones Escogidas in Cansinos's Spanish translation, states that Machado was already known in Spain through the work that had been previously translated into French, which is almost certainly a reference to the two Delpech volumes, especially given that the stories in the Spanish translation are all stories that had previously appeared in Delpech's Quelques Contes. The Spanish translation, however, omits five stories that appear in the original Portuguese volume and the French edition, and also doesn't exactly retain the title, opting for the even more generic Narraciones 
Escogidas (Selected Stories). ${ }^{2}$ The forward to the Spanish version-perhaps written by Cansinos himself - also laments the fact that none of Machado's work, neither short story nor novel, had ever been published in Spanish translation in Spain: "Pero hasta hoy, que sepamos, no ha visto la luz entre nosotros una colección de cuentos como la que ahora ofrecemos a nuestros lectores, ni menos una novela del gran narrador, como por ejemplo, esas deliciosas Memórias Póstumas de Bras Cubas" ("But until now, as far as we know, there hasn't appeared among us a collection of short stories such as the one that we are now offering to our readers, nor even a novel by the great narrator, such as, for example, those delicious Posthumous Memoirs of Brás Cubas"; 9).

Though a native of Spain, Rafael Cansinos Assens was intimately connected to Jorge Luis Borges and the literary cultures of Latin America. He was born in Seville in 1882 (thus seventeen years Borges's senior) and was residing in Madrid when the Borges family moved there in 1919. He was a prolific writer, critic, and translator, as well as the founder of the Ultraista avant-garde movement in Spain (and, oddly enough, the first cousin, once-removed, of Margarita Cansinos, better known as Rita Hayworth). He translated from a number of European and non-European languages, producing Spanish-language editions of Goethe, Dostoevsky, De Quincey, Marcus Aurelius, The 1001 Nights, and a single volume of Machado's short fiction, "versión castellana directa del português" ("Spanish version translated directly from the Portuguese"; Narraciones escogidas title page). Perhaps most significantly for the fate of Latin American literature, Cansinos was also a mentor to young Borges while his family was living in Madrid.

Having lived in Geneva since 1914, Borges and his family moved to Madrid in 1919, where the twenty year-old Borges met Cansinos for the first time. In his 1970 "Autobiographical Essay," which Borges wrote in English for the American publication of a volume of his stories entitled The Aleph, Borges stresses the formative influence that Cansinos had on him: "Next, we went to Madrid, and there the great event to me was my friendship with Rafael Cansinos-Asséns. I still like to think of myself as his disciple"

2 The stories in Cansinos Assens's Spanish-language edition are: "La deseada," "Trio en la menor," "Mariana," "Doña Paula," "Adán y Eva," "Entre santos," "La echadora de cartas," "Un hombre célebre," "El enfermero," "El canónigo o metafísica del estilo," and "Ahasvero." They appear in this order, which is different from the order of the stories in the original Portuguese edition, which Delpech retains. The stories omitted from Cansinos Assens’s volume are: "Uns braços," "A causa secreta," "O diplomático," "Conto de escola," and "Um apólogo." 
(221). ${ }^{3}$ In this same essay, Borges describes the weekly tertulias, or salon-style literary gatherings, that he attended in Madrid, over which Cansinos presided:

Every Saturday night I would go to Café Colonial, where we met at midnight, and the conversation lasted until daybreak. [. . . Cansinos would propose a subject-The Metaphor, Free Verse, The Traditional Forms of Poetry, Narrative Poetry, The Adjective, The Verb. In his own quiet way, he was a dictator, allowing no unfriendly allusions to contemporary writers and trying to keep the talk on a high plane. (222-223)

Cansinos was, thus, a professor of sorts for Borges, lecturing and leading discussions on a variety of literary topics. Borges regarded him as a man with voracious, multi-cultural reading habits and a model of the literary life, a "symbol of all culture, Western and Eastern" (222). Cansinos may also have served as the early inspiration for the librarian figure who looms so large in much of Borges fiction, considering Borges's description of Cansinos's house: “Once, I went to see him and he took me into his library. Or, rather, I should say his whole house was a library. It was like making your way through a woods" (222).

The reverential tone in which Borges speaks of Cansinos, even fifty years after their initial encounter, is indicative of the crucial role he played in Borges's intellectual development, particularly his development as a reader. In a 1968 interview, Borges was categorical about this formative influence:

A writer called Rafael Cansinos-Assens, an Andalusian Jew, also had a great influence on me. He seemed to belong to every century. I met him in Spain. Of the people I've mentioned, apart from my father, whom I can't judge because I was too close to him, those who have impressed me the most were Macedonio Fernández and Cansinos-Assens. (qtd. in Burgin 58).

\footnotetext{
3 The spelling of Cansinos's name varies from publication to publication. For the sake of orthographic consistency in this article, I have opted for the unhyphenated, unaccented spelling, yet have retained the spelling as it is found in any quoted sources.
} 
Borges also praises Cansinos in a variety of other interviews and essays throughout his life, even specifying the areas of his intellectual apprenticeship that were nurtured by him. For Borges, he represented an extensive, almost encyclopedic knowledge of Western literature and thought: "Sentí que al despedirme de Cansinos, de ese viajero inmóvil que exploró los reinos de la tierra, me despedía de todas las bibliotecas de Europa y de su acumulado saber" ("I felt that, in bidding farewell to Cansinos, to this stationary traveler who explored the kingdoms of the world, I was bidding farewell to all the libraries of Europe and their accumulated knowledge"; "Prólogo" 28). In his "Autobiographical Essay," Borges credits Cansinos with helping him develop certain reading habits_- "I was stimulated by him to far-flung reading" (222) - and in an interview given in 1984, just two years before his death and sixty-five years after his year-long mentorship with Cansinos in Madrid, Borges praises him as a great translator and "one of the people who impressed me most in my life" (qtd. in Burgin 226). The praise that Borges heaps on Cansinos, right up until the end of his life, is so expansive as to be nearly hyperbolic.

It should come as no surprise, then, that all of Borges's biographers make special note of this influence on Borges. Alejandro Vaccaro remarks that Cansinos was one of the few people who had a lasting impact on the young Borges, arguing that he "fue fundamentalmente el hombre que más cautivó a Georgie [Jorge Luis Borges] por aquellos días, quizá sólo comparable a otras dos devociones del Jorge Luis adolescente: su padre y Macedonio Fernández" ("was, fundamentally, the man who most captivated Georgie [Borges] in those days, perhaps only comparable to two other devotions of the adolescent Jorge Luis: his father and Macedonio Fernandez"; 157). Maria Esther Vasquez, in her biography Borges: esplendor y derrota, writes that Borges "se consideró discípulo [de Cansinos] (lo repetía a menudo) hasta el final de su vida [. . .] Le fue fiel hasta el final" ("considered himself his disciple (he often repeated this) until the end of his life [. . . He was loyal to him until the end"; 62). In a 1979 interview, mere months before Borges's eightieth birthday, Borges still maintained he was a follower of "el culto de Cansinos-Assens" ("the cult of Cansinos Assens"; Carrizo 295). The importance of Cansinos on the literary formation of Borges cannot be overlooked, given that Borges himself asserted it throughout his life, even long after he left Madrid for Argentina. 
It thus seems probable that Borges, under the tutelage of Cansinos and the influence of his "far-flung" reading, read his mentor's translation of Machado, published in Madrid just three years before he and his family arrived there. This is by no means hard evidence of Borges having read Machado, much less evidence of any direct literary influence or anxiety thereof (see Bloom). Rather, this coincidence of geography and tongue, of a double Latin American dislocation-Machado in translation in Spain, by way of France, Borges physically in Spain, by way of Switzerland-problematizes the reigning assumption that Borges never read Machado and sheds new light on the connections between Brazilian literature and the literatures of the rest of the Americas.

Surprisingly, it is an American author, John Barth, who provides some further evidence in support of this literary-historical connection. In his 1991 essay, "Borges and I: a mini memoir," Barth recounts the impact that both Machado and Borges had on his early fiction. In Machado he found a model for a Postmodernist sensibility that had yet to be named and of which he would become one of the principal practitioners in the U.S. He goes on to confess that Machado's influence on his fiction waned considerably after his first few novels and that as Machado's impact faded, Borges became the major influence on his work. Yet the most striking aspect of Barth's essay, in the context of this study, is neither his catalogue of influences nor the conceptual linking of Machado and Borges - which is not uncommon, especially among American authors. Amazingly, in "Borges and I: a mini memoir," Barth recounts several conversations he had with Borges about Machado de Assis.

While at times Barth is tantalizingly forgetful or unsure about certain of Borges's responses, on one point he is quite clear: Borges had read and admired the work of Machado de Assis. In all the literature on these two authors, this appears to be the lone claim that Borges read Machado-a real revelation, further supported by the connection that both Latin American authors have to Cansinos. One such conversation took place on the occasion of Borges's 1975 visit to Michigan State University, where Barth had also been invited to speak. Barth reports from this encounter that "Borges himself, needless to report, was quite familiar with the writings of Joaquim Machado de Assis and with the salutary influence on Machado of Laurence Sterne's Tristram Shandy" (166). This statement is remarkable for a variety of reasons, chiefly because Barth is quite unambiguous about the fact that Borges read Machado. But not only was Borges "quite 
familiar" with Machado's works, he further knew that Laurence Sterne's fictional experimentation had been a "salutary influence" on Machado's work. This reveals a familiarity with Machado's work on the part of Borges that surpasses a mere passing acquaintance with his name or reputation. Furthermore, this passage seems to indicate that Borges had read Machado's Memorias Póstumas de Bras Cubas, since this novel is more clearly influenced by Tristam Shandy than any other in Machado's œuvre.

Barth goes on to recount another conversation about Machado, at the end of their day in East Lansing:

We ended the evening quite late around a small table in the host's kitchen: my wife, Borges, y yo. I was tired, and no wonder; Borges seemed tireless. He and I spoke briefly of Machado de Assis and of Gershon Scholem and the Kabbalah. (176)

While this is hardly unequivocal evidence that Borges read Machado in Cansinos's (or even Piquet's) translation, it does further support the possibility that Borges was introduced to Machado's work by his Spanish mentor. If true, this is perhaps a crucial missing link between Brazilian literary history and that of the rest of the continent, with far-reaching implications for our understanding of the development of literary fiction in the Americas and the development of experimental or avant-garde fiction in the late- $19^{\text {th }}$ and early- $20^{\text {th }}$ centuries.

For Cansinos's part, the translation of Machado's work was no mere mercenary contract job; in fact, it seems likely that he even wrote the unattributed preface to Narraciones Escogidas, given the way he praises Machado in a number of other books, essays, and reviews. In Verde y dorado en las letras americanas, Cansinos demonstrates familiarity with Machado's novels as well, comparing the prose of Brás Cubas to that of the world's greatest novelists: "Tal, en la novella, ese Machado de Assis, el autor de las Memórias Póstumas de Braz Cubas, en cuyas páginas sentimos el paso vigoroso y suelto de los grandes maestros del género" ("Just as, in the novel, we have this Machado de Assis, the author of the Posthumous Memoirs of Brás Cubas, in whose pages we feel the vibrant, loose stride of the great masters of the genre"; 545). Cansinos clearly deemed Machado's fiction important enough to warrant translation into Spanish, and it would, therefore, seem that he translated Machado's stories because he found them to be of great literary merit, and perhaps, then, pushed them on his young Argentine disciple. 
The enthusiasm Cansinos had for Machado in 1916, when he published his translation of Machado's short fiction, never seems to have waned. In a 1932 review of a book of Machado's correspondence, Cansinos calls him "uno de esos clásicos modernos que la lengua portuguesa encontró en el Brasil" ("one of those modern classics that the Portuguese language encountered in Brazil") and compares him to the other great Portuguese-language novelist of the $19^{\text {th }}$ century: "Él tiene la cálidad clásica, como Eça de Queiroz" ("He has the quality of a classic, like Eça de Queiroz"; "Crítica" 9). Such a claim would certainly have aroused the curiosity of Borges, who praises Eça effusively in a number of essays and interviews, calling him "el mayor novelista de Portugal" ("the greatest Portuguese novelist") and "entre los grandes del mundo" ("among the greats of all the world"; Obras recobradas 1931-1955 296). In another essay, Cansinos champions the Spanish novelist Francisco Camba and, in doing so, again connects Machado and Eça: “Así, por ejemplo, al leer a Camba yo no puedo acordarme sino de Eça de Queiroz, de Machado de Assís [sic], de nombres portugueses y brasileños" ("Thus, for example, as I read Camba I can't help but recall Eça de Queiroz and Machado de Assis, among Portuguese and Brazilian writers"; La Nueva Literatura 118). A few years after the publication of the volume of Spanish translations, Cansinos attests to the fact that Machado's work had gained recognition in Spain: "De esa literatura [Brazilian literature] copiosa y llena de interés, sólo algunos nombres, como los de Olavo Bilac en la poesía, y Graça Aranha y Machado de Assis, en la novela, han alcanzado resonancia entre nosotros" ("From such a copious and interesting literature, only a few names, like that of Olavo Bilac in poetry, and Graça Aranha and Machado de Assis in the novel, have had an impact among us"; Verde 535). Cansinos's enthusiasm for Machado's fiction and his desire to bring it to the attention of the Spanish-speaking world strongly suggest that Borges would have become familiar with Machado's work under Cansinos's tutelage, which is further supported by John Barth's anecdotal assertion.

It is important to recognize that Machado's name and work were still relatively unknown outside of Brazil during the first few decades following his death; these early translators and critics in Latin America and Europe-Piquet, Delpech, and Cansinos-were promoting his work and making it available for an international audience almost singlehandedly, prophets in the wilderness announcing to the world (or, at least, their linguistic corner of it) that Brazil had produced a master of literary fiction, 
to be counted among the world's greats. That Borges was a self-described disciple of one of these early champions - in Spain, no less, and right around the time of the publication of the Spanish-language translation of some of Machado's most radically subversive short fiction-must be one of the great coincidences in the history of Latin American fiction, and perhaps one that should have a far-reaching impact on our understanding of the development of literary fiction and form in the Americas.

Five years after the appearance of Cansinos's volume, Machado's work was first published in English, in the United States. Daphne Patai notes that "[ $t$ ]he history of Machado translations in English begins rather inauspiciously-and late" (86), and, indeed, Machado's work took quite a bit longer to appear in English than in French or Spanish and not nearly as much of it was translated into English. Three of his short stories were published in English in 1921, in an anthology entitled Brazilian Tales, translated by Isaac Goldberg-alongside stories by José Medeiros e Albuquerque, Coelho Neto, and Carmen Dolores-and his novels did not appear in English translation until the 1950s. William Grossman's English translation of Brás Cubas was brought out by Noonday Press in 1952, over thirty years after Goldberg's translations and over seventy years after the publication of both the serial and single-volume editions of the original in Rio de Janeiro. Fortunately, Dom Casmurro and Quincas Borba appeared in English in quick succession thereafter-in 1953 and 1954, respectively-in translations by Helen Caldwell and Clothilde Wilson.

Goldberg's 1921 anthology included three short stories by Machado, all of which were also featured in Cansinos's volume and Delpech's complete translation of Várias Histórias into French. These three were "Viver!" (translated as "Ahasveru" in Cansinos's Spanish volume and "Life" in Goldberg's), "A cartomante" (translated as "La echadora de cartas" and "The Fortune-Teller"), and "O enfermeiro" (translated as "El enfermero" and "The Attendant's Confession"). Furthermore, in one of those strange coincidences of world literary history-perhaps one that proves that the worldwide audience for experimental or subversive fiction is very small indeed-Cansinos seems to be directly connected to Goldberg and the first appearance of Machado's work in English translation. In addition to the volume of short stories he translated and the various articles and reviews wherein he praises Machado, Cansinos appears to have been in contact with Goldberg, or, at very least, these two critics and translators were reading each other's work. 
Among his many other Spanish translations, Cansinos also translated one of Goldberg's critical works, Studies in Spanish-American Literature (La literatura hispanoamericana: estudios criticos, in Cansinos's Spanish version), the Spanish edition of which was published by Editorial-América in Madrid, the same press that published Narraciones Escogidas. Thus there is a crucial connection between two of Machado's very early translators: not only were they contemporaries, but Cansinos was reading and translating Goldberg's scholarly work on the literatures of the Americas. Here, the intricate web of world literature is seemingly spun without regard for notions or conventions of power dynamics between the periphery and the center, the new world and the old, former colonies and former empires. It also seems likely, given the professional relationship between Cansinos and Goldberg, that Goldberg's translation of Machado was prompted, informed, or inspired by Cansinos's earlier Spanish-language volume, especially since Goldberg's translations are of stories that are also featured in the Cansinos volume. Thus, one can trace a direct trajectory or lineage of Machado in translation, from the initial publication of his works on the Rua do Ouvidor in Rio by Laemmert and Garnier Irmãos, to the French translation and publication by the same publishing house, Garnier Frères (this time in Paris, for a European audience), to a Spanish awareness of Machado as a result of the French editions, to the Spanish translations by Cansinos, to the English publication of a few of these translations by Goldberg, who was in contact with Cansinos, his colleague and translator in Spain.

Like Piquet, Delpech, and Cansinos before him, Goldberg was a true champion of Machado's work. In 1922, he authored a volume of Brazilian literary history entitled, predictably, Brazilian Literature, which contained a chapter on Machado and was meant to serve as a companion volume to the Studies in Spanish-American Literature volume translated by Cansinos. Across the Atlantic, in English and Spanish, Goldberg and Cansinos were in dialogue about Machado and the very recent developments in Latin American letters. Both translators were intimately aware-in the first and second decades after his death in 1908-of the importance of Machado's novels and short fiction, as well as their place within the canon of Latin American literature. They were also interested in contemporary movements in Latin American literature, specifically the modernist impulse (called vanguardismo in Spanish-speaking countries and modernismo in Portuguese-speaking ones), and how the fiction of Machado's late period fit or did not 
fit into that paradigm. Indeed, Goldberg even saw Machado as a writer who defied classification, "a literary law unto himself” (Brazilian Literature 143) —in other words, an experimental writer who transformed the canon and its conventions with his radically subversive prose.

Goldberg and Cansinos represent two of the very few writers, scholars, and translators who championed Machado outside of Brazil in the decades following his death and who had a keen interest in the literary transformation that was then taking place in Latin America, in Hispanophone and Lusophone countries alike. Like Cansinos, Goldberg understood that Machado was a writer of rare quality who had been neglected up to that point, unfairly relegated to the periphery, in part because of the language in which he wrote:

Had he been born in Europe and written, say, in French, Machado de Assis would perhaps be more than a name today - if he is that - to persons outside of his native country. As it is, he has become, but fourteen years after his death, so much a classic that many of his countrymen who will soon gaze upon his statue will surely have read scarcely a line of his work. (Brazilian Literature 142)

In addition to his clever definition of a classic - a recognizable figure in statuary that largely goes unread-Goldberg shows an astute awareness of how Machado's nationality and language had served to marginalize his work during his lifetime, even as he attempts to make Machado much more than just a name in the English-speaking world.

As a quartet, Piquet, Delpech, Cansinos, and Goldberg were the earliest proponents of Machado outside of Brazil and the Lusophone literary world, exposing wide swaths of readers in the cultural capitals of the Americas and Europe to his works of fiction, both novels and short stories. It cannot be said for certain that Jorge Luis Borges was counted among these readers, but the early translation and publication of Machado's novels in Montevideo and Buenos Aires, Borges's presence in Spain around the time of the publication of the first Spanish-language edition of Machado's stories, and his intimate disciple/master relationship with Cansinos-Machado's translator and dedicated advocate-reveal an intriguing link between Machado and Borges and the literary cultures - traditionally held to be separate - that they represent. Indeed, perhaps all of 
these early translators served, in some way, to connect two of Latin America's most prolific and compelling fiction writers, acquainting Borges with his esteemed predecessor from the neighboring Brazil via translations published in Montevideo, Paris, and Madrid. These strange pathways of Machado's work in translation, from Rio de Janeiro to Rio de la Plata, from Paris to Madrid, demonstrate the ways in which translators blur the lines between periphery and center, connecting authors, readers, and literary cultures which, like Brazil and Hispanophone Latin America, are often held to have developed in relative isolation from each other. Further research into these interconnected literatures might ask the now-glaring question: Why did Borges never write about or mention Machado de Assis? Though the answer to this question would be speculative, at best, further investigations could shed light on the similarities between the fictional works of Machado and Borges, reveal Borges's attitudes toward Brazilian culture generally (and Afro-Brazilian culture in particular), and provide a detailed analysis of Borges's rare statements about Brazilian literature. 


\section{REFERENCES}

Barth, John. Further Fridays: Essays, Lectures, and Other Nonfiction 1984-1994. Boston: Little, Brown and Company, 1995.

Bloom, Harold. The Anxiety of Influence: A Theory of Poetry. Oxford: Oxford UP, 1973.

Borges, Jorge Luis. "Autobiographical Essay" in The Aleph and Other Stories: 1933-1969. New York: Dutton, 1970.

------ Prólogo. El candelabro de los siete brazos. By Rafael Cansinos-Asséns. Madrid: Alianza Editorial, 1986.

------. Textos Recobrados 1931-1955. Buenos Aires: Emecé Editores, 2001.

Burgin, Richard, Ed. Jorge Luis Borges: Conversations. Jackson: UP of Mississippi, 1998.

Cansinos Assens, Rafael. "Crítica Literaria: Correspondencia de Machado de Assis, colegida e anotada por Fernando Nery, de la Academia Brasileira de Letras.—Rio de Janeiro, 1932." La Libertad. 8 May 1932: 9.

------. La nueva literatura 1917-1927: Colección de estudios críticos. Vol. 4. Madrid: Editorial Páez, 1927.

------. Verde y dorado en las letras americanas: semblanzas e impresiones críticas (1926-1936). Madrid: Aguilar, 1947.

Carrizo, Antonio, ed. Borges el memorioso: Conversaciones de Jorge Luis Borges con Antonio Carrizo. Mexico City: Fondo de Cultura Económica, 1982.

Fitz, Earl E. Brazilian Narrative Traditions in a Comparative Context. New York: The Modern Language Association of America, 2005.

Goldberg, Isaac. Brazilian Literature. New York: A.A. Knopf, 1922. 
-----. Ed. and Trans. Brazilian Tales. Boston: The Four Seas Press, 1921.

-----. La literatura hispanoamericana: estudios críticos. Trans. Rafael Cansinos Assens. Madrid: Editorial América, 1922.

------. Studies in Spanish-American Literature. New York: Brentano's, 1920.

Machado de Assis, Joaquim Maria. Epitaph of a Small Winner. Trans. William Grossman. New York: Noonday, 1952.

-----. Dom Casmurro. Trans. Helen Caldwell. New York: Noonday, 1953.

-----. Mémoires posthumes de Braz Cubas. Trans. Adrien Delpech. Paris: Garnier Frères, 1911.

-----. Narraciones Escogidas. Trans. Rafael Cansinos-Assens. Madrid: Editorial América, 1916.

-----. Obra completa. 3 vols. São Paulo: Editora Nova Aguilar S.A., 1985.

-----. Quelques Contes. Trans. Adrien Delpech. Paris: Garnier Frères, 1910.

-----. Philosopher or Dog?. Trans. Clotilde Wilson. New York: Noonday, 1954.

Pasero, Carlos Alberto. "Machado de Assis, cuentista." Cuadernos Hispanoamericanos 598 (2000): 53-66.

Patai, Daphne. "Machado in English." Machado de Assis: Reflections on a Brazilian Master Writer. Ed. Richard Graham. Austin: University of Texas Press, 1999.

Rocca, Pablo. "Machado de Assis, Escritor do Rio da Prata." Cadernos de Letras da UFF. Vol. 38, pp. 35-49: 2009.

Sontag, Susan. Where the Stress Falls: Essays. New York: Farrar, Straus and Giroux, 2001. 
Vaccaro, Alejandro. Georgie (1899-1930): Una vida de Jorge Luis Borges. Buenos Aires: Editorial Proa, 1966.

Vázquez, María Esther. Borges: Esplendory derrota. Barcelona: Tusquets Editores, 1999. 